\title{
Lung-Sparing Cancer Surgery
}

\author{
David R. Sanderson \\ Mayo Medical School, Scottsdale, Ariz., USA
}

Lung cancer is a major public health problem of growing importance throughout the world with frustrating long-term survival of under $15 \%$. A majority of patients are unresectable at time of diagnosis, and even in those deemed operable, comorbid problems often limit efforts at successful resection. Procedures designed to preserve pulmonary function demand special skills and ingenuity.

In this issue of Respiration, Ohta et al. [1] report their experience with bronchial sleeve and carina resection allowing complete lung preservation. They had two patients with squamous cell cancers and one each of mucoepidermoid and adenoid cystic carcinoma. With an aggressive approach in spite of proximal airway involvement, they were able to avoid sacrifice of lung parenchyma and yet achieve prolonged survival. The rarity of potential candidates for this type of surgery limits the opportunity for any one medical center or surgeon to gain great experience. Ohta et al. found only 4 out of 1,673 patients, or $0.24 \%$, in whom this was possible.

In a collected series from Antwerp, Van Schil [2] found a 5 -year survival of $62 \%$ in patients with N0 disease, $29 \%$ for $\mathrm{N} 1$ and $31 \%$ in N2 disease after bronchial sleeve resection. A report by Yoshino et al. [3] compared patients treated with pneumonectomy and those undergoing sleeve resection and found no significant difference in survival, suggesting the lung-sparing procedure would have merit for long-term quality of life. Sioris et al. [4] from Helsinki reported 40\% 5-year survival after bronchoplastic resection in 28 patients over a 20 -year series.

The opportunity for aggressive resection and lung preservation will doubtless remain small. Clearly, careful selection of patients and accurate preoperative staging are critical to minimize risks for postoperative complications and early recurrence of malignancy. However, the experiences noted above argue against a nihilistic approach in these proximally occurring lesions. Pulmonary physicians and oncologists need to maintain an ongoing dialogue and treatment planning with their surgical confreres.

\footnotetext{
References $\quad 1$ Ohta Y, Yachi T, Oda M, et al: Bronchial sleeve resection with complete preservation of the lung for carcinoma. Respiration 2001;68: 528-532.

2 Van Schil PE: Long-term results after bronchial sleeve resection. Verh K Acad Geneeskd Belg 2000;62:229-241.

3 Yoshino I, Yokoyama H, Yano T, et al: Comparison of the surgical results of lobectomy with bronchoplasty and pneumonectomy for lung cancer. J Surg Oncol 1997;64:32-35.

4 Sioris T, Salo J, Mattila S: The role of bronchoplasty in the treatment of lung cancer. Ann Chir Gynaecol 1997;86:31-37.
}

\begin{tabular}{ll}
\hline KARGER & @ 2001 S. Karger AG, Basel \\
Fax +41 61 306 1234 34 & \\
$\begin{array}{l}\text { E-Mail karger@karger.ch } \\
\text { www.karger.com }\end{array}$ & $\begin{array}{l}\text { Accessible online at: } \\
\text { www.karger.com/journals/res }\end{array}$
\end{tabular}

\begin{tabular}{l}
\hline Dr. David R. Sanderson \\
Mayo Clinic Scottsdale \\
13400 E. Shea Boulevard, Scottsdale, AZ 85259 (USA) \\
Tel. +1602 301 8265, Fax +1 6023014869 \\
E-Mail dsanderson 958@md.northwestern.edu
\end{tabular} 